\title{
Europeanization through Migration Policies: Legislative Comparison between Civil Law Systems and Common Law Systems

\author{
PhD Shkelzen Hasanaj
} \\ Department of Law, University of Pisa, Italy
}

Doi: 10.2478/ajis-2018-0049

\begin{abstract}
Within the European Union there are several states that have implemented laws, often following different paradigms, to cope not only with the increase in migratory flows, but also to foster the integration and participation of the migrants themselves in socio-political and economic life. In recent decades, immigration into Europe has become a matter of primary and strategic importance for the definition of both internal policies and the external relations of the Union. The progressive settlement of substantial national and ethnic groups poses important economic, social and cultural challenges, to which the policies implemented have so far only partially responded. Guiding concepts like integration, assimilation and respect for diversity still struggle to find an adequate realization in the reception policies of the European states. In this regard, a real revolution in this area was the realization of the "common basic principles" of 2004, which made member states become aware of the respect for fundamental rights, non-discrimination and equal opportunities for all (Niessen,. Schibel, 2007), and it later became a mere "Common agenda for Integration". In this context, we can recall the decision of the Council and of the European Parliament n.1983 / 2006 which proclaimed 2008 as the European Year of Intercultural Dialogue. With this research, we intend to analyze the regulations concerning the migration of European governments and how they have changed over time, paying particular attention to the activation of inclusion strategies in some European Union countries; at the same time, we intend to find a strategy for a possible cooperation in the management of migratory processes. The integration regulations launched in Italy, Germany, France and the United Kingdom will be examined from the 1940s to 2015 and a comparative study will be conducted between the Community policies and the policies of four countries chosen to highlight common features and divergences.
\end{abstract}

Keywords: Migration in Europe, Migrant crisis in Europe, EU immigration policy, Legislative comparison

\section{Introduction}

In order to empirically identify the validity of the interpretative hypotheses, from a comparative perspective, and oriented, essentially to highlight the affinities and differences, it was considered important to deepen the characteristics of migratory paths and the impact of policies in the Italian context. and in the German one focusing the research on the acquisition of citizenship.

In particular, the research has moved, first of all, from the analysis of the regulatory framework in force in the field of migration policies, which allowed me to summarize the tools used to protect the lives of foreign citizens and at the same time respecting their ethnic, cultural and religious diversity.

In this regard, we will try to provide some guidelines for their functioning, with the purpose in the end, to bring out and test the validity of the interpretative hypotheses and the corresponding political proposals for safeguarding and protecting foreign communities in respect of foreign communities in Italy. The reason of this choice on the "state of citizenship" (effective citizenship) in 
the regulatory systems in force in Germany, France, the United Kingdom and in Italy, the latter considerably called into question at a national level as well in Europe, showing the existence of multiple questionable elements, especially at a regulatory level, which, however, are likely to be truthful, by an excessive reduction and fragmentation of migration policies. The more and more intense increase of migratory flows in Italy and the choice by migrant citizens of a long-term and definitive permanence means that immigration is a structural fact and is called upon to undertake important structural reforms that make it possible to overcome the logic of a temporary migration, and on the other hand, to restart an effective recognition process able to protect foreign communities in the territory.

\section{Research Methods}

The methodology adopted for the research work is that of a bibliographic construction on the subject, that is the Europeanization through migration policies: legislative comparison between civil law systems and common law systems.

Therefore, it is a qualitative approach study .

The selection criteria made to obtain data from the sources were different. Regarding the data related to the different migration policies in Europe: application and results, the published data disclosed in two sources were consulted mainly, first of all by taking into consideration the current regulatory framework on migration policies, which allowed me to synthesize the tools used to protect the lives of foreign citizens and the impact of policies in case studies. In this case, the data were collected by the government institutions of the respective States and by the censuses carried out over the years.

The second main source from which the relative data of our research come is Pew Research Center. The illustrations in this report are based on the best sources available for each State studied at the time of research. We were careful to many sources to determine the size and impact of the policies in foreign communities and the factors that would influence the expected changes in each community, including models of integration, participation in socio-political life, religious affiliation, etc.

Information on the impact of policies, sources and data was analyzed, including censuses, demographic surveys, general population surveys. Data collection and censuses were the primary source for estimates of the impact of migration policies in foreign communities in the case studies.

\section{History and Development of the Migratory Phenomenon in Italy}

Italy has historically known the presence of foreign groups within its territory. In the nineteenth century in the Kingdom of Sardinia the state issued special passports to foreign residents according to their social status: first-class passports for merchants, shopkeepers, civilian soldiers, military, second-rate for under-officers, workers, day workers .

Even at the time of unification the foreigners who had participated in the expedition of the Thousand for the conquest of the Kingdom of the Two Sicilies were present in large number (Einaudi, 2007).

Let us not forget that until then citizens of the Italian states considered each other foreigners, especially for the very wide linguistic and cultural differences among the different regions, more evident when they are looking for work from the south to the center of the peninsula (Vitale, 1995).

After the end of the Second World War and the birth of the republic there was a new attitude towards foreigners. The Italian constitution of 1948 integrated as an important part of its principles regulations against discrimination and racism, redesigning the condition of the foreigner. Even today, articles 3 and 10 of the Italian constitution recite:

"Art. 3 All citizens have equal social dignity and are equal before the law, without distinction of sex, race, language, religion, political opinions, personal and social conditions. It is the duty of the republic to remove the obstacles of an economic and social order which, by limiting in fact the freedom and equality of citizens, prevent the full development of the human person and the effective participation of all workers in the political, economic and social organization of the country 
(Cfr. art. 3. Cost.)

Art. 10 The legal status of the foreigner is regulated by the law in accordance with the rugulations and international treaties. The foreigner, to who the effective practise of democratic freedom guaranteed by the Italian Constitution is prevented in his country, has the right to asylum in the Republic territory, according to the conditions established by the law. The extradition of the foreigner for political crimes is not permitted "(Cfr. art. 10. Cost.)

The new Republic thus definitively abolished the racial laws adopted during the fascist period, giving foreigners civil rights, regardless of their origin.

\subsection{From a country of emigration to a country of immigration: push factors}

During the years of economic boom Italy, from a country of emigration, becomes a country of immigration. Several authors try to explain the pushing factors that caused this radical change. Ugo Melotti claims that the first immigrations to Italy happened accidentally, in fact many of those who would have rather gone to the traditional countries of immigration of Central and Northern Europe, finding the borders closed, begin to head towards Italy. Luca Einaudi, explains the decisive reasons that in his opinion determined the increase of foreigners in Italy: "The Italian economic growth between the 1950s and 1980s was one of the largest in Europe. This growth has increased the demand for unskilled foreign labor, offering low incomes compared to the Italian standards ".

\subsection{Entry reasons}

The first significant migratory phenomena involving Italy as a destination country had to do with people coming from from poor and developing countries in the sixties and seventies; in most cases the flows consisted of undocumented migrants who entered Italy in search of a job to improve their economic situation. According to Luca Einaudi, the growth of migration in Italy in the seventies and eighties is due to the economic boom and not to the crisis that hit Europe during the years 1973-74; therefore the growth of migratory flows coming from poor and developing countries towards Italy has gone hand in hand with the economic growth of the country.

To reinforce this thesis, we can see that, between the end of the 1950s and the beginning of the 1980 s, the Italian per capita income rose by $92.3 \%$ compared to the average value of European countries (Einaudi, 2007).

Also the neoclassical immigration theory is based on this correspondence between the economic development phase and the beginning of migratory flows, indicating the differences in income as the cause of international migration flows. Economic motivations are flanked by the requests for political asylum proposed in the same years by men and women fleeing from countries like Argentina, Brazil, Chile, Eritrea, Ethiopia, Somalia (Melotti, 2004).

\subsection{The first legislation of the Ministry of Labor on migration: circular letter no. 51 of 1963}

Until the early 1980s, an estimate of the real number of foreign residents in Italy was missing and there were great uncertainties regarding people who had a regular residence permit. Between the seventies and eighties, the Ministry of the Interior declared that the number of residence permits granted had risen from 150,000 during 1970 to 300,000 in 1980, thanks also to the amnesties granted by the government in those years (Colombo., Sciortino, 2004a).

It is very important to understand that the first initiatives for the regularization of migratory flows were implemented following the slowdown in the economic boom and the increase of difficulty for foreign citizens to place themselves on the labor market; as Einaudi writes, Italy could not afford mass immigration because of the difficulties in building effective selective mechanisms for workers coming from developing countries.

The first institutional intervention was the transfer of skills in the field of migration from the Ministry of the Interior to that of Labor, to deal with employment problems for foreign workers. This event marks a passage, also in the political perception of immigration, which from a peripheral issue becomes a real problem that will assume a central role in the planning policies of the labor 
market.

The Ministry of Labor in the Circular letter No. 51 of 1963 introduced the issuance of a residence permit subject to the following requirements: the authorization by the UPL (Provincial Labor Office), the employment contract, the go-ahead of the central police station and the entry visa for work reasons. The residence permit for workers had a duration of one year and could only be renewed by people in possession of a regular contract, without any extension in the event of unemployment. This legislation was conceived as a form of defense of the Italian workforce following the decrease in economic growth; in fact, before a company could hire a non-EU worker, the presence or absence of requests from Italian citizens to perform that particular job had to be verified by the competent office (UPL).

Einaudi reminds that foreign citizens who wanted to enter Italy without a work contract, first passed by a tourist visa, to then look for a job on the spot. Once the job was found, a request for recruitment from abroad was presented ex post followed by a return in their homeland, thus simulating the subsequent entry as the first regular entry, flanked by the authorization to work and the residence permit (Einaudi, 2007). These rigidities have immediately created the conditions for the accumulation of a large number of immigrants without residence permits and with undeclared work. What follows, starting with the emanation of the 1986 immigration law, is a different, more liberal policy.

\subsection{The Foschi law of 1986, the first immigration law}

The Foschi law integrates the International Convention on Migrant Workers No. 143 of 1975, which came into force in 1978, and is based on the following assumptions: "Labor is not a commodity and that poverty, wherever it exists, is a danger to the prosperity of all, and it recognizes the solemn obligation of the Organization to support the implementation of appropriate programs, inter alia, to implement full employment, in particular by means of facilitating transfers of workers, including migrations of manpowe".

Among the most important articles regarding the condition of migrant workers of this convention are the art. 10 and 11: "Art. 10 Each member for whom the convention is in force undertakes to formulate and to implement a national policy aimed at promoting and guaranteeing, with methods adapted to national circumstances and practices, equal opportunities and treatments in the field of employment and profession, social security, trade union and cultural rights, as well as individual and collective liberties for people who, as migrant workers or family members of the same, are legally in its territory.

Article 11. 1. For the purposes of the application of this part of the convention the term "migrant worker" designates a person who emigrates or has emigrated from one country to another, in view of an occupation, otherwise than for his own behalf; it includes any person regularly admitted as a migrant worker ".

Although the introduction of this legislation has greatly improved the working conditions of migrant workers, other types of situations and other categories of workers remained outside.

The Foschi law did not stop at the regularization of the working status of immigrants, in fact one of the novelties of this law was the recognition of other types of rights to the immigrant population, including family reunification and the amnesties for the regularization of those people who were in a condition of irregularity, as well as the rights related "to the use of social and health services and the maintenance of cultural identity, to school and to the availability of housing" (Einaudi, 2007).

Among the main failures of this law is the lack of recognition of self-employment and hawkers, thus ignoring the importance of the economy immersed in Italy, where most of the immigrants were employed (Ascoli,1979). Moreover, employers could not personally select workers, they had to select them according to the list ranking, those higher up the list had more opportunities to find a job. Finally, it completely lacked recognition of the importance of labor recruitment abroad. 


\subsection{The first intervention on immigration: the Martelli law of 1989}

With the law proposed by Claudio Martelli (vice-president of the Council of Ministers of the Socialist Party), known as the "Martelli law", a series of important innovations emerge, aimed at improving social status and facilitating the recognition of social rights and the cohabitation of immigrants in Italy.

Between the end of the 1980s and the beginning of the 1990s, the growth of migratory flows and a period not particularly flourishing for the Italian economy facilitate the proliferation of prejudices and xenophobia towards foreign citizens, especially those of African origin. Very soon the issue of racism and discrimination takes a central role in public opinion, also following various news reports, among which probably the most significant being the killing of Jerry Masslo by a gang of robbers (Sardo, 2014).

For the first time there was a strong mobilization from the population, culminating with the participation of more than two hundred thousand Italian and foreign citizens at the demonstration organized in Rome against racism and for the rights of immigrants (Grillo, 1989). This popular awakening calls into question the entire management of the migration phenomenon by the political system and the regulations that had been adopted until then, which were no longer considered able to face the new reality.

The most important points of the Martelli law were:

a. a regularization of foreign workers already present in Italy (amnesty);

b. revision of law 943, guaranteeing equal rights and health, social security and housing guarantees for foreign workers;

c. access for a greater number of foreigners to university education and professional institutions;

d. a flexible scheduling of migratory flows for only non-EU immigrants without a job (which, however, must not be identified with the "limited number");

e. the abolition of the geographical reserve for non-European asylum applicants.

Martelli judged as a priority the regularization of foreigners without residence permits, influenced by trade unions and left-wing and Catholic associations. Within the framework of government, Christian Democrat exponents elaborate a new law on the freedom of circulation for those who want to work in Italy, for which communication to the government was sufficient even just a month before departure. Proposal that meets the heavy criticism of the Northern League; as Einaudi writes, Umberto Bossi thus identified his three enemies regarding the issue of immigrants: "The left-wing hunting for the votes of immigrants, the Catholic church in search of marginalized people to care for and funds to manage, and finally the entrepreuneurs, exploiters of the great capital " (Einaudi, 2007).

The Martelli decree was approved on December 22, 1989, although in Parliament it was modified with respect to the original draft, for example the geographical reserve for non-EU asylum applicants is abolished, so as to recognize the refugee status to all those fleeing their Countries for reasons of racial, religious, political persecution regardless of the geographical area of origin. This change reflected the decrees of the Geneva Convention concerning the status of refugees and asylum applicants and the Dublin Convention on the responsibility of the State to analyze the asylum applications in the European Community. A further novelty is the recognition of forms of self-employment. for foreigners, allowing a supervision on this category.

The decisions for the regulation of annual flows for foreign workers were entrusted to the Ministries of Foreign Affairs, Internal Affairs and Labor.

With regard to expulsions, these become applicable only to people who had violated entry and residence provisions and to people convicted for serious reasons of public security. Moreover, the citizen subject to expulsion was granted 15 days to move away from Italy on his own initiative, otherwise the citizen was carried out with accompaniment to the border by the law enforcement.

Given the scarcity of police resources, both in the means and in the accompanying personnel, and in the firm opposition by the anti-racist associations, the expulsion measures have been applied in small numbers.

In the Martelli law, there were no new ideas for the adoption of effective policies for the 
integration of permanent immigrants: the issue of public housing for immigrants that was not resolved and that became so much a custom that entire families of immigrants were staying with acquaintances or thanks to the help of the community of origin or of the churches that offered them housing support. Conte's proposal to include them in the quotas for social housing, these were followed by perplexities and disputes both by a large part of the political world and by the citizens (Einaudi, 2007). Following were the regions to take charge of new initiatives for the 'inclusion of foreigners in the rankings of social housing, but this possibility was left entirely to the arbitrariness of each region, in fact those that were governed by the center-left-wing were more open to this possibility, those governed by the center-right-wing, on the contrary, were more restrictive.

In a very tense political climate and with a mixed majority (PDS, Verdi, Cristiano Sociali, Psi, Democratic Alliance), the Dini government, in the few months of its duration (1995-96), tried to start a new immigration policy (Decree 489/95).

At the center of the new decree there were the regularization of irregular immigrants $\left({ }^{1}\right)$ and new procedures concerning expulsion, contained in Article $7(2)^{2}$

The Dini decree lapsed rapidly because the Constitutional Court declares the impossibility of resubmitting to the Parliament the decrees expired before their conversion into law.

\subsection{An organic law: $n$. 40/1998, cd. Turco - Napolitano}

In 1996 the center-left wing wins the elections and for the first time after years of technocratic governments the political stability allows us to elaborate a new migration policy, treating immigration as a structural phenomenon that involves not only amnesties, but a necessary planning. The government creates a commission for the preparation of a bill on the entry and residence of non-EU citizens within which the Minister for Social Solidarity Livia Turco, appointed by the Prime Minister Romano Prodi, and the minister of the Interior Giorgio Napolitano work.

Turco declares the three most important goals of the new law:

"a) the fight against illegal immigration;

b) the planning of flows;

c) the construction of a new policy in terms of citizenship, where the immigrant was no longer considered a B-class citizen" (La Stampa, 1986).

Regarding the role played by associations and trade unions, Einaudi writes: "The associations proposed a series of measures in the field of work, such as booking lists in consulates, as a way to signal the willingness of foreigners to come to work in Italy, with call based on the age of registration on the lists. These immigration quotas had to match the labor needs. They also argued that it was not necessary to authorize work to allow the search for a job for a period of two years. Regarding the expulsion issue, they asked to consider it as an exceptional measure of seriousness and not as an instrument to compensate the lack of an immigration policy " (Einaudi, 2007).

After months of work, the legislative proposal begins the parliamentary process of approval on January 31, 1997 and is approved in 1998. For the first time all the immigration regulations are in a single text.

With the entry into force of the new law, a broad process of recognition of the fundamental

\footnotetext{
${ }^{1}$ Within one hundred and twenty days from the date of entry into force of this decree, foreigners present in Italy on this date, holding a passport or an other equivalent document, including the identity certificate issued by the diplomatic or consular representation in Italy of the country of origin, to which an employer issues a written declaration of his / her availability to the immediate regular, permanent or fixed-term employment of not less than six months, or to hire as a seasonal job, otherwise to declare to perform a continuous work, employed by Italian citizens legally residing in Italy, they can apply at the police headquarters territorially in charge for a residence permit for work reasons. http://www.latenda.eu/decreto.htm

${ }^{2}$ Article 7 of the Decree-Law of December 30, 1989, n.416, converted, with modifications, by the law n. 39 dated February 28, 1990, is replaced by the following: "Art. 7 (Expulsion as a security measure) 1. The foreigner convicted, or against whom the penalty is applied upon request under articles 444 and following of the criminal procedure code, for one of the crimes provided for by articles 380 and 381 of the same code, can be expelled from the territory of the State, provided he/she is socially dangerous ". http://www.latenda.eu/decreto.htm
} 
human rights began, in particular regular foreigners were granted all civil rights with equal treatment in this field and judicial protection, in the relations with public administration and in the access to public services. The new law was more flexible in granting residence permits for work, family and study reasons: for the first time foreign students are granted the right to work up to 20 hours per week. With the entry into force of the law a real political process of integration also begins, for which a special fund for migratory policies is created; a very important attention is also dedicated to the fight against discrimination, starting from the access of social housing, to education and health (Einaudi, 2007).

A novelty are the set aside quotas introduced by Article 18 "assigned preferentially to non-EU countries, with which the Minister of Foreign Affairs, in agreement with the Minister of the Interior and with the Minister of Labor and social security, has concluded agreements aimed at regulating entry flows and readmission procedures. Within the framework of such agreements, specific agreements can be defined regarding flows for seasonal work, with the corresponding national authorities responsible for labor market policies in the countries of origin".

The application of this rule was very important in the following years, consider the case of the Albanian migrant population, for which, thanks to these agreements, potential immigrant workers could apply directly to the consulates. Also for students the same policy is followed, for which thousands of aspiring students could apply for enrollment at the Italian university at the consulates (today in Italy, more than 11,000 Albanian students are enrolled in Italian universities).

With regard to the new residence permits for subordinate workers (permanent), these lasted for two years, at the end of which the renewals could be accessed, the first of them with a duration of more than four years.

In addition to the rules for temporary residence permits, it was also possible to access the "Residence Card" after five years of permanent residence. With the creation of this kind of residence permit, Italy recognized that immigration could no longer be interpreted as a temporary phenomenon, but that, on the contrary, a dynamic and permanent immigration was by now the majority of cases that the country would have found itself to face.

The new law also provided for more restrictive rules, with respect to the Martelli law, regarding controls and expulsions: rejections could be made not only at the border, but also in the vicinity; moreover, it is forbidden to enter the Italian territory for five years for all those who were responsible for expulsion before. This is accompanied by specific protections, such as prohibition of expulsion for children up to sixteen years, for pregnant women, for those who hold a residence permit, for relatives of Italian citizens and, finally, for asylum applicants waiting for protection.

Furthermore, Turco-Napolitano arranges the temporary residence centers, which are in turn expected by the Schengen agreements, for the identification and expulsion of irregular citizens in the territory. The maximum period of stay in the centers was 30 days from the first entry and within 48 hours from the entrance the judge had to validate the detention in the CPT or its immediate release. However, especially in the debate over the last few years following the Primavere Arabe, these centers have been seen as a prison-like structures, as they deprive people of their individual liberty without having committed any crime, risking that expulsions take place without an evident cause.

Regarding the aspect of security and control of flows, the Turco-Napolitano law predicted very strict sentences - up to three years of imprisonment - against the exploiters of illegal immigration and 15 years for traffickers who exploited prostitution and minors. To facilitate the persecution, Turco proposed a specific residence permit for women who had reported the people who had been guilty of rape or who had forced them into prostitution. This new residence permit was scheduled for a period of six months and could be renewed.

With regard to access to citizenship, the proposal included the inclusion of the ius soli criterion, which considered the acquisition of citizenship by foreigners born abroad after five years of residence and by children born in Italy at the first year of elementary school, provided that one of the parents was born in Italy or both born abroad, but with at least five years of residence in Italy. However, this proposal was not taken into consideration by the Parliament, leaving a legislative gap that still today cannot say to have been fully filled.The art. 46 of the Turco-Napolitano Consolidated Text considered the creation of a Commission for Immigrant Integration Policies, chaired by 
Giovanna Zincone in the Department of Social Affairs of the Presidency of the Council of Ministers.

This Commission introduced an innovative concept based on the idea of Reasonable integration according to two lines (Article 3 of Law 40/1998): «Integration is a process of nondiscrimination and inclusion of differences, therefore of contamination and experimentation of new forms of relationships and behaviors, in the constant and daily attempt to hold together universal principles and particularisms. It should prevent situations of marginalization, fragmentation, ghettoisation, which threaten the equilibrium and social cohesion, and affirm universal principles such as the value of human life, the dignity of the person, the recognition of female freedom, the valorisation and protection of childhood, on which exemptions can not be granted, not even in the name of the value of difference ".

The two lines to be followed for the new concept of reasonable integration were on one hand integration as the integrity of the person, on the other hand integration as a positive interaction for a peaceful coexistence, for which no group considers the other as harmful. Consequently, a government has the duty to create the favorable conditions in which various communities belonging to society are not excluded from civil life, thus controlling aggressive attitudes (Zincone, 2000).

\subsection{The developments of the Bossi - Fini law 189/2002}

We have seen how the center-right wing forces, which in the years of the Turco-Napolitano reform were in opposition, tried to prevent its implementation, primarily the Lega Nord, which launched a campaign against immigration in 1999, organizing the revocatory referendum of the law (the constitutional court in February 2000, declared the referendum inadmissible because it was against the international agreements of Schengen). Also the party of Gianfranco Fini, National Alliance, worried about the new landings coming mainly from Albania and Kosovo proposes in 1999 a bill introducing the crime of clandestinity and a series of particularly stringent controls for immigrants, which included also identification via fingerprints upon arrival in Italy.

The following year, the Lega Nord, AN and Forza Italia make an electoral agreement and the revision of the immigration law is one of the main points of the alliance program. On March 30 , 2000, the new coalition presented a bill in Parliament against immigration in all its forms, putting together with the legislative proposal, especially through the Lega Nord and its leader Bossi, a strong attack on the new multiracial model, starting from a renewed idea of the primacy of the state over the nation. The new bill highlighted the traditions and historical values of the Italian society, presenting clear objectives, among which stand out:

a. fighting illegal immigration;

b. rejecting irregular immigrants who were in the territory, making them definitively lose their right to return to Italy;

c. even stricter laws against traffickers, and against those who exploit and promote prostitution, with sentences up to 18 years of imprisonment;

d. reviewing the relations of cooperation with the countries that had not fulfilled the agreements signed to combat immigration;

e. enrollment at Italian consulates abroad to work in Italy: immigrants were thus granted a social security number with which they could enter Italy, entry whose economic burden would fall on the people who had applied for labor.

f. 36 months for family reunification, linked to the regular payment of taxes.

The League also takes a critical stance towards the Muslim population, using strongly xenophobic rhetorical arguments, aimed above all at preventing the construction of mosques. This propaganda move had excellent results in the regional elections of 2000 , and, especially after the attacks of September 11, 2001, the Northern League (Lega Nord) increased its consensus in the electorate thanks to the propaganda against Islam.

The 2001 elections thus take place in a climate in which especially the center-right wing, together with the Northern League (Lega Nord) and the National Alliance, uses the identification between immigration and crime as one of the main mechanisms to defeat the center-left coalition.

The electoral victory of the center follows a new process of reform on the issue of immigration and the bill drafted by Bossi and Fini is based solely on the principle of facilitating expulsion and is 
against illegal immigration.

The basis of Bossi and Fini's proposal was the idea of avoiding long-term settlements and also the non-recognition of pension contributions for migrants, so the proposal was to give non-EU workers temporary contracts (not more than three years) after which they had to leave the Italian territory. To this a quota policy is added for the individual regions, based on the needs of this new type of temporary workers.

These bills are challenged by many associations that call into question human rights: the nonEU worker became only labor-power without any right in case of unemployment or dismissal. Seeing the reaction and the protest of civil society and associations involved in the assistance to migrants, the crime of illegal immigration is left aside, however forced expulsions increase and the period of stay in the Cpt centers is doubled from thirty to sixty days, to prevent migrants from returning to freedom due to the impossibility of identification.

After a few months from the elections, Bossi and Fini present the guidelines of their legislative proposal to the Council of Ministers, following what they had affirmed throughout the election campaign, and this is approved on September 14, 2001. To reach the final approval, the part on leaving the national territory of those people for whom the employment contract had expired, were unemployed or who had been fired is changed: a further six-month period of renewal of the residence permit is granted.

The penalties proposed for the crimes of second entry into the national territory remain unchanged after the expulsion measure order and at the third entry the penalty provided from 1 to 4 years of imprisonment.

In addition, the employer, before recruiting a non-EU worker had to check whether there was a request from Italian citizens and EU citizens to do the job. The new law did not recognize the contributions paid by non-EU foreign workers, which favors in many cases the accession to illegal and paid off the books jobs.

Another restrictive rule introduced by the law is the limitation of people who could take advantage of family reunification. In fact, non-EU foreigners residing in Italy are granted reunification only for dependent children and the spouse, but for the other family members this right was not recognized.

Finally, the detection and registration of fingerprints at the time of the issue or renewal of the residence permit are introduced ex novo. The law was so focused on security issues that it lacked an organic asylum law and a law for political refugees.

\subsection{The 94/2009 security package (Maroni Law)}

Following the Bossi-Fini law, approved by the parliament in 2002, the legislative intervention on the most significant issue was the Maroni law of 2009. In this law n. 94/2009, known as the "security package", for the first time regulatory restrictions on public safety are placed, and these directly affect immigrants: the crime of entry and illegal stay in the national territory, punishable not only with prison, but also with the obligation to pay a fine ranging from 5,000 to 10,000 euros.

Articles 361 and 362 of the Penal Code also punish the public official and the public service officer who do not report a crime of which they have been notified in their practise or because of their functions: all public offices with which the foreign citizen enters in contact therefore have the obligation to report the irregular status, excluding health workers and (municipal, regional, state) teachers.

All non-EU foreign citizens have the obligation to prove the validity of the residence permit to access services (excluding health and education) and for the completion of the civil status documents (marriage, birth registration, recognition of the natural child, registration of death). This is also followed by the impossibility for irregular people present in the territory to report the employer both for a possible undeclared employment and for exploitation.

With regard to reunification, the obligation to present the certification by the municipality of residence of the housing identity of the accommodation is added.

To these rules further legislative instruments are added:

- the introduction of the residence permit with points, with the consequent risk of losing the 
available credits and the relative authorization to stay in the territory;

- the issuance of the EC permit for people who have a long-term permit, from which the possibility of access to many social services derives, provided they are able to demonstrate their knowledge of the Italian language;

- the introduction of a quota between $€ 80$ and $€ 200$ for each renewal and issue of the residence permit;

- the abolition of the silence-assent regime after 180 days for the approval by the prefectures;

- the introduction of the voluntary private city guard (or city patrols) to guarantee security.

Furthermore, the CPTs became CIEs (identification and expulsion centers), with a consequent extension of the maximum maintenance period. Always following the spirit of the law, also for the acquisition of Italian citizenship the requirements become more rigid, in fact to be able to apply for citizenship you need a marriage certificate from 6 months to 2 years.

The punitive part is further exasperated: non-EU foreigners who do not show the documents to the public security authority can be punished with penalties from 6 months to 1 year of imprisonment, in addition there-s the imprisonment from 6 months to 3 years for those people who rent a property to the irregular foreigner in the national territory.

Finally, there's an added obligation for the operators of internet point, money transfer, call center services, to register and maintain a photocopy of the client's ID document for 10 years, as well as the obligation to report to the police within 12 hours the clients without a residence permit.

These rules set out by the security package were strongly condemned not only by the public opinion, but also by the European Court of Justice which rejected the crime of clandestinity, because in contrast with the European directive EC 115/2008.

\section{History of Migratory Flows in France}

The history of French migratory flows is usually traced back to the French colonial past in Morocco, Tunisia and Algeria, but these have also developed for internal causes, such as the need for foreign labor to cope with the demographic crisis, caused during the twentieth century above all by the two world wars, during which those who had enlisted in the French army without being born in France had already a central role (Viet, 1998).

During the second decade of the 19th century, France experienced a strong industrial growth, with an increase in the demand for foreign labor, initially only for short periods, then, thanks also to migration policies, as final appropriations (Bardet, 1999).

Migration policies in France are historically based on the assimilation of other cultures to the French one that we can define as a unilateral integration. One of the basic requirements for becoming a French citizen is the knowledge of the French history, of the French language, but it is equally binding to recognize ourselves entirely in the French culture, leaving no space for traditional, linguistic and cultural customs of the country of origin, a kind of "memory deletion" of all that the immigrants identified themselves with until they arrived in the host society. In return, the French state recognizes to all civil and political rights (Withol De Wenden C, 1990).

With the recognition of ius soli, the French nation proves that to be a French citizen there are no bonds of either ethnicity or color, but only a necessary identification of oneself as French and the recognition of French culture as one's own culture. This form of recognition had already been used in the colonial period, during which it was required for the occupied populations to identify themselves with the French culture, in exchange for the full recognition of their social and political rights.

Therefore, France recognizes and directs the assimilation of foreigners in an institutional manner, and it is easy to notice it both in public schools and in administrative offices. Near the end of the nineteenth century, foreigners residing in the French territory were almost a million, thanks to the economic growth and the demand for foreign labor by the industry. With the outbreak of the First World War the demand increases, to replace the workers who were called to the front, where about $11 \%$ of adult males lose their lives, causing a drastic reduction of the population (Noiriel, 2007). In response to the demographic crisis that broke out between the two wars, there are about 
300,000 new arrivals from countries such as Greece, Spain, Portugal and, after the world war, also from Italy.

After the first world war France had about 3 million immigrants contributing to the reconstruction of the country, thanks also to the policy followed by governments to not limit the flow, conceived as a primary need not only for the reconstruction of the country, but also for the demographic growth.

\subsection{The establishment of the first Société d'immigration}

As a consequence of the massive request for immigration into the French territory, in 1924 some business, industrial and agricultural organizations formed the Société générale d'immigration (SGI) to coordinate the procedures for the selection and entry of foreigners. The State therefore delegates to private interest groups the whole procedure of coordination and recruitment of foreign workers in France. According to estimates from 1924 to 3030 about 406.950 foreigners are recruited, most of whom came from Belgium, Austria, Czechoslovakia, Yugoslavia, Romania, Italy, Greece, Lithuania ( Weil, 1995).

The 1929 crisis has repercussions on the whole industry, agriculture, the banking system, and trade, causing a major drop in production and very high unemployment, not only in the United States, but also in Europe. The decrease in production and the very high rate of unemployment inevitably also have an effect on immigration, which is significantly reduced until the outbreak of the Second World War. This entails a change of course in the French policy of control of flows and a xenophobic sentiment of the French population, who felt threatened by foreign workers, willing to work even in bad conditions.

With the approval of the Nationality Code, a new way to control and manage immigrant flows is sought, which also continues during the Vichy government, in which French citizens of foreign origin are banned from accessing public functions, thus beginning an operation of denaturalization of the citizenship, which is accompanied by a new repression also against refugees, openly denying the egalitarian principles of the 1789 revolution. We can remember the case of the Jews, to who the access public functions, French citizenship and the possibility of pursuing certain professions, such as that of lawyers and doctors are forbidden.

\subsection{The new code for immigration (CESEDA)}

In the aftermath of World War II we return to encourage immigration, De Gaulle himself supports the need for foreign labor in the absence of men needed for the reconstruction of the country. His idea was to support a selective and assimilationist policy of new migratory flows, focusing on their provenance and their degree of integration into the French culture. This leads to the adoption of the "CESEDA" immigration code of 1945, which regulates the entries and stay of foreigners and asylum applicants in the French territory.

\subsection{The first committee for the population and the family of Georges Mauco (1945)}

In 1945 the establishment of the Committee for Population and the Family begins, a body with the task of informing the government on the needs and problems of migratory populations. Leading the committee was Georges Mauco, who expressed the need to reformulate a new immigration and naturalization policy for foreigners that would adapt and defend the interests of the French national unity. With these ideas the selective recruitment of immigrants based on their region of origin begins. De Gaulle chooses to favor immigration from northern Europe to support a young, peaceful immigration also able to work. Italy was one of the beneficiary countries of this new political line, in fact in the immediate post-war two Italian labor recruitment offices are opened in Milan and Turin, which is followed by a policy of privilege towards Italian immigrants also with regard to family reunification (Barou, 1984). In the following years there is a strong growth of citizens coming from the colonies, above all Algerians employed in the seasonal, but also permanent jobs, in the enterprises of the north of the country, which in less than ten years reach about 350.000 regular 
entries (Bonet, 1976; Costantini, 2009).

Many French citizens disapprove the new opening towards the countries initially considered non-preferential, especially those in the northern areas of Africa, which were believed to put at risk the French culture and the nation itself, building ethnic minorities difficult to assimilate. The government thus tries to limit family reunification requests from non-preferential countries, but a significant decrease in entry flows from Algeria occurs only with the Franco-Algerian war of 1954 (Sayad, 2002).

\subsection{The 1973 energy crisis and the ad hoc decree against migratory flows (1974)}

In the years of the energy crisis of 1973 , which overwhelms all the countries importing oil, there is a consequent increase of unemployment rate that affects, in France as in many European countries, also migration policies: only those immigrants who had already formed a family and skilled workers in sectors that are important for the economic growth of the country could remain (Simone, 2002).

In the years between 1978 and 1989, Valéry Giscard d'Estaing presented a draft law on repatriations, also forced, of immigrants from non-preferential countries; it proposed a provision that had the impression of being directed against the Algerians, which provided for the non-renewal of the residence permit, for annual fees, to those who were unemployed for more than 6 months. The proposal recommended that around 500,000 Algerians were expelled from France in 5 years (Schor, 1998).

However, the decree went against the European Convention for the protection of human rights and fundamental freedom of 1950, signed, among others, by France itself. In particular, Article 8 of the Convention is very clear regarding the issue of family reunification:

"Article 81 . Everyone has the right to the respect for one's private and family life, one's domicile and correspondence.

2. There can be no interference by a public authority in the practise of this right unless such interference is provided for by law and constitutes a measure which, in a democratic society, is necessary for national security, for public security, for the economic well-being of the country, for the defense of order and for the prevention of crimes, for the protection of health or morals, or for the protection of the rights and liberties of others ".

\subsection{The Eighties, the right-wing project: the Pasqua law}

At the beginning of the Eighties, the propaganda of the right-wing electoral campaign for the 1983 elections put the accent above all on the citizenship granted to the children of immigrants, once again with a specific reference to the second generations of Algerians born in France. The battage leads Jean-Marie Le Pen's extreme right party to more than $10 \%$ of the polling stations. In this period, for the first time, second generations of immigrants were actively approaching the political world, claiming their rights not only to feel to be part of the French nation, but also to be recognized as subjects that play a decisive role in the social and political life. of the country. This gives rise to a new political performance by the left government, which proposes a residence permit for ten-year for workers, as well as the establishment of a single residence title.

In the legislative elections of 1986 the Regrouping for the Republic (the coalition of the rightwing and ex-Gaullist parties) won the elections, thanks also to an electoral campaign focused mainly against immigrants.

An exemplary measure was the so-called Pasqua law of 1986, thanks to which the prefects (and no longer the judges) are the ones who deal with the forced repatriation of irregular immigrants, accompanying them for threat to the public order, and the limitation of renewal of the ten-year stay. In 1986 thousands of students oppose themselves to the governmental policies on education and citizenship; during the the elections of 1988, with the electoral victory of the left-wing and its allies, migration policy changes. 


\subsection{The abrogation of the Pasqua law and the new Joxe law}

The new government presided over by François Mitterrand repeals the Pasqua law and lands on the Joxe law. After years of proposals and political negotiations, finally in 1993 the naturalization reform is approved: it is necessary to manifest the will between 16 and 21 years, while in case of marriage two years of cohabitation are needed (Costantini, 2009).

\subsection{The Balladaur government and the return of the Pasqua law (1993)}

In 1993 new legislative elections were held, won by the center-right wing. The new head of government, Balladur, proposes to return to the Pasqua line as a restrictive move on extended residence permits and family reunifications (Bussetta, 1993).

\subsection{The 1997 Debré bill}

On 6 November 1996 Debré proposed a new immigration law, approved by the Assembly on February 26, 1997, in which on one hand considered the regularization of certain categories of foreigners, on the other it strengthened the power of the police, weakening the judicial authority.

In 1997 new elections were held, won by the left-wing together with the communist parties (Calcalaterra, 1998; Chemillier-Gendreau, 1998). Jospin immediately declares the intention to send to the prefects a circular letter containing the request to analyze case by case the irregular situations triggered by the Pasqua-Debré laws (Taieb, 1998).

\subsection{The 2006 law and immigration reform}

The new 2006 law attempts to promote selective immigration, adapting migratory flows to the country's economic growth needs.

The concession of the "welcome and integration contract", contained in the reform, considered that the right to enter French territory should be granted to children between 16 to 18 students, or with special potential qualifications, on the condition that they showed they were willing to remain there permanently, with the signing of the civic agreement and the attainment of complete linguistic training. Any foreign citizen wishing to enter and settle in the French national territory had be able to demonstrate that they wanted to integrate themselves, starting from the respect of the principles and the knowledge of French history and language.

Another important part of the reform is focused on the regulation of economic immigration, through the assignment of a specific stay, valid for three years, designed for the support and integration of foreign talents, able to contribute decisively to the economic, social, scientific, cultural and sporting development of the nation.

For workers who have a contract of at least one year, the carte de sèjour temporaire is issued, the duration of which depends on the duration of the employment contract.

With the new rule, to apply for family reunification it's necessary to have certain requirements, starting from a guaranteed minimum income. The inclusion of this legislation is much debated, demonstrating how much the issue of family bond and the possibility of reunification for the foreign population is a considerable problem.

For people from countries with political crises that do not ensure the authenticity of the deeds, a simple family certificate or a declaration of the family connection isn't enough, but DNA testing is necessary. Once the reunification has been obtained, the children of the immigrants have the obligation to sign the above-mentioned welcome and integration contract with the state.

Measures to oppose illegal immigration are strengthened: if in 2002 there were 10,000 expulsions, in 2005 they increased to 20,000 , in 2006 up to 24,000 . Following the approval of the reform, in the years 2007-2008 the expulsions still increase, reaching 29.729 immigrants; in short, a growth of $80 \%$ of the expulsions only in 2008, compared to 2006 (Costantini, 2009).

In 2006 the admission exceptionnelle au sèjour was also approved, which is a regularization on an exceptional basis, following a knowledge and assessment of the immigrant situation by the 
prefects.

\subsection{Limits of the French model: Sarkozy and the Roma policy of expulsion, August 2010}

The case of the Roma ethnic population is emblematic for understanding the limits and possibilities of the French model. At the beginning of August 2010 the Sarkozy government issued a ministerial circular letter addressed to the prefects asking for the evacuation of the 600 Roma camps currently present on the French territory and the expulsion of irregular Roma, for reasons of public security. Approximately 700 people are repatriated to Romania and Bulgaria within a month. The aforementioned circular letter did not go only against the fundamental principles of the French Republic and the Declaration of the Rights of Man and of the Citizen of 1789, but also against articles 14 and 18 of the treaty of the European Union about the free movement of European citizens.

The mass expulsions of European Roma citizens are accompanied by an economic reward, for which each adult is offered 300 Euros for repatriation and in some cases even a thousand Euros to entire families, to encourage a voluntary return.

A member of the European Parliament, Renate Weber (ALD, RO) regarding these voluntary repatriations of the Roma people declares:

"France is using tricks: they call it voluntary repatriation, while it's a clear violation of the European and international law".

Ultimately, the Sarkozy government saw in the Roma people a community that creates problems of public security and that does not want integrate themselves according to the norms and customs of the French model.

\section{An Example of Roma Inclusion and Integration Policies in Spain}

The Spanish example is emblematic for the difference with which the issue of the Roma communities was dealt with, since unlike France and the European States that have dealt this with policies focused on non-recognition and evictions, Spain has managed to solve the integration problem. According to many surveys and publications, only Spain houses about 970 thousand people of Roma ethnicity, about $2 \%$ of the entire population, who are called gitanos or gypsies, without a negative meaning; the gypsies themselves share this denomination with pride and feel like gypsis and at the same time Spaniards.

There is much talk in various European countries of the poor inclusion of Roma communities in the host society: the French case, but also the Italian one, show that voluntary or mandatory repatriation, behind an economic reward, does not solve any of the social problems that persist. Returning to Spain, according to the report of the European Union Agency for Fundamental Rights of $2009,92 \%$ of the Gypsies live in apartments or single houses of which half is also the owner, as opposed to what happens in France and Italy, where more than $80 \%$ live in shacks or degraded apartments. This happens thanks to a universal welfare, with equal opportunities for housing, in this way the gypsy is evaluated not as belonging to his or her ethnic community, but as belonging to the social groups with greater economic difficulties.

Another important part of this model of integration is the inclusion in the education of children, inclusion in the health service and access to the work of adults belonging to these communities. This form of insertion has the primary aim of promoting and improving the life of the Gypsies, and through this improvement integration.

$50 \%$ of the Gypsies in Spain have a regular job thanks to employment policies.

As for education, almost all Gypsy children are enrolled in elementary schools and distributed in various schools close to their place of residence and are accompanied on this path by social workers and mediators.

Every year the Spanish government invests about 36 million Euros for this integrative system, which has succeeded in making only a small minority of the Gypsy community live in poor conditions and in shanty towns (Cala, 2010). 


\section{Migration Policies in Germany}

Currently the German nation is one of the countries with the highest number of immigrants in Europe (about $9 \%$ of the resident population is of foreign origin). Despite this fact, Germany finds it difficult to identify itself as a country of immigration. (Melotti, 2004).

The migration policies of the last decades were entirely aimed at facing the social problems of temporary workers only.

After the Second World War, immigration was sustained by the German governments uninterruptedly until the energetic crisis of 1973, to cope with internal labor needs for the reconstruction of the country, stipulating numerous agreements for the recruitment of foreign workers. The first bilateral agreement, the one with Italy, was signed in 1955 and it allowed Italian workers to go to Germany to be employed; the subsequent agreements were established with Spain in 1966, with Turkey in 1961, with Morocco in 1963, Portugal in 1964, and Yugoslavia in 1966.

An important role for the growth of immigration in Germany is also assumed by the facilitated entry for asylum seekers and political refugees guaranteed by the German constitution.

The policies implemented by the government were not very incisive and aimed more at primary reception needs such as the establishment of dormitories, the recognition of workers' health rights, not considering the activation of structural integration policies necessary and immediate.

\subsection{One of the first restrictive laws on facilitated expulsions (1965)}

In 1965 the law about the facilitation of expulsion of foreigners was approved, which gave full power to the German authorities to grant or withdraw the residency permit, to promote the expulsion for those who didn't follow the requirements, but also for citizens subject to conviction (also for violation of the traffic rules) or considered dangerous for public safety.

Non-EU workers who worked interruptedly in Germany for a minimum of 5 years could apply for the special work permit. Until the end of the 1960s, the regulations adopted for migratory policies considered for family reunifications at least 3 years of permanence in the territory, while for the children of immigrants born in Germany it was impossible to become German citizens (ius sanguinis) (Kammerer, 2003).

The German government in the Seventies began to become aware of the growing number of immigrants who wanted to stay longer in the national territory and to meet these new needs it proposes a strategy based primarily on reception and integration, mainly aimed at those who had a guaranteed work, who had obtained family reunification and who had acquired the right of residence in the German society over the years.

In 1972 the Ministry of Labor proposed for the first a legislation regarding the integration of foreign workers into the federal territory, with a very clear aim, that of comparing the foreign worker to the German worker in the field of social policies, even if it was not easy to face problems related to housing, health, trade union involvment, pension problems of the elderly, children in schools, problems of religion, of language.

The second core of the German immigration strategy was based on activating a return policy in the country of origin and restricting entry for work reasons.

\subsection{The 1973 energetic crisis and the closure of borders for foreign citizens}

The 1973 crisis induced also Germany to close the borders for immigrants, with the exception of certain sectors of economy (hotel, construction and health).

The immigration debate begins to be a central point in the political debate of all the guidelines, especially during election campaigns.

In 1982, after the constructive distrust of the Schmidt government, Helmut Kohl was appointed Chancellor and he convened the early elections in 1983 and won them. 


\subsection{The "pay-to-go" law of 1983}

During the Kohl government in 1983 a new law was approved to facillitate the return to the country of origin of the immigrants, stimulating them with "return prizes": each unemployed immigrant received about 10,500 marks and the return of the whole sum paid in advance for social security and social benefits.

Just to give some significant data, Italians' returns exceed 785,000 people making up $17 \%$ of all returns, while the second group with the largest number of returns is Yugoslavia with 500,000 people, more than 10\%; also Greeks count a high number of returns, more than 300,000 , about $7 \%$. However, incoming flows continued to increase over the years.

P. Kammerer explains that the number of immigrants in the years 1973-79 was about 4 million and between 1979-80 it grew to 4.4 million, while between 1980-89 it remained at the same level (Kammerer, 2003). With the fall of the Berlin wall a new phase begins in the history of migration in Germany, with a further increase in migration flows coming mainly from neighboring countries, such as Poland and Yugoslavia. As a result, in the 1990s there were around three million more immigrants (7.3 million total) than in the 1980s.

\subsection{The new integration law for foreigners, 1990}

In 1990 the Kohl government issued a new law about the integration of foreigners. The first part of the law establishes the criteria that foreigners must have to obtain the right to reside in Germany:

a. prove that they possess the financial requirements for maintenance,

b. prove that they have an adequate housing,

c. prove that they do not need government assistance,

d. to have a clean record,

e. be faithful to the republic,

f. prove to know the German language.

The residency permit was granted to those who had without interruption a temporary residence permit for eight years and could also be issued for humanitarian reasons or for the reasons provided for by the international treaties stipulated by Germany, as in the case of asylum seekers, or of those who were in a state of illegality for humanitarian reasons.

\subsection{Towards a new immigration policy (1999-2000)}

The "reform law", which came into force on January 1, 2000, is today conceived by various scholars as the real turning point in migration policies in Germany, as it overcomes the identification of migrants as guest workers and also the ius sanguinis. In fact, one becomes a German citizen:

- if one of the parents has been legally and continuously living in the national territory for at least 8 years;

- if one of the parents has the right of residence indefinitely for at least 3 years;

- in cases where a child has dual citizenship status, at the age of eighteen, the possibility to choose between one of the two citizenships is given;

- $\quad$ after only 3 years of stay for those under 16;

On the other hand, marriage with a German citizen does not automatically give the right to German citizenship.

The Green Card is also introduced, which allowed the granting of a work residence permit to certain categories of workers, among which the entry of the IT specialists from Asia and especially from India stand out.

In 2002 the new Chancellor Gerhard Schroder issues a consolidated text on immigration which abolishes all the rules that included restrictions for asylum seekers and for access to an employment contract; family reunifications and the immigration of entire families are incentivized, especially those with children under 12 years of age, to avoid that after that age they find it difficult to enter in the country's school system. The Bundesamt Fur Migration und Fluchtinge is established, a competent center that selects and establishes the maximum number of entry flows 
for foreigners in Germany, providing facilities for the entry of qualified workers, from countries of the European Union.

Finally, it becomes compulsory for foreigners to take German language courses as a requirement for integration into the host society.

\section{Migration Policies in the United Kingdom}

In the case of United Kingdom, but also in France, migration policies are closely linked to the colonial past. The two countries differ as France seeks the assimilation of immigrants into the national culture, while United Kingdom historically sees cultural, linguistic, racial and religious diversity as a factor of the nation's cultural wealth, and therefore it encourages this by giving to migrant communities full autonomy and recognition and supporting the construction of ethnic communities.

\subsection{Colonial age}

To understand the history of British immigration policies, it is necessary to begin by analyzing British policies beginning from the colonial age, where the acquisition of British citizenship was regulated with decrees by the Crown, which sanctioned the distinction between citizens who were entitled to citizenship and foreign citizens who could acquire it after years of residence and by specific request, swearing loyalty to the monarchy.

"British Nationality" and "Status of Aliens" (1914) represent the first legislative intervention that establishes that every citizen born in the colonial territory is a natural-born British citizen. Actually not all the citizens of the Commonwealth countries could circulate among the various countries of the crown, this also due to the wide autonomy and the different policies in the various Commonwealth countries.

\subsection{British Nationality Act 1948}

In contrast to what happened at the same time in Germany and France, where immigration was encouraged to cope with the post-war reconstruction and economic growth, a very different policy was followed in England, focusing the attention on encouraging immigration from the countries of the Commonwealth, with the "British Nationality Act" decree of 1948.

"(1) This is a citizen of the United Kingdom and Colonies or a man who is under any enactment for the time being in force in any country mentioned in subsection virtue of that citizenship.

(2) Any person having the status aforesaid may be known as a British subject or as a Commonwealth citizen; and accordingly, in this Act and in any other enactment or instrument whatever, the expression "British subject" and the expression "Commonwealth citizen" shall have the same meaning.

(3) The following are the countries hereinbefore referred to, that is to say, Canada, Australia, New Zealand, the Union of South Africa, Newfoundland, India, Pakistan,

Southern Rhodesia and Ceylon » (British Nationality Act, 1948).

In the early years of the war and in the immediate post-war years (1950), immigration towards England consists of small specific ethnic groups, such as Jamaicans, West Indies, Cypriots, Italians and people coming from Eastern Europe.

\subsection{The facts of Notting Hill}

Since the end of the 1950s, the phenomenon of immigration has experienced very intense flows, coming for example from the Caribbean; estimates say they were around 100,000 units only in London in 1961, in specific areas such as North Kensington and Notting Hilll.

Entire families lived there lived, mostly in a situation of economic hardship and in poor housing conditions, which often are opposed by the locals: various fascist groups, such as those of Sir 
Oswald Mosley, or even the gangs of Teddy Boys, begin a fight against the colored kids, with writings on the walls, like No colour bar here and Keep Britain White, coming up to physical violence and the burning of the Caribbean café.

During the month of August 1958 there were two weeks full of civil disorder at Notting Hill. On August 30th in North Kensington, a group of white boys belonging to fascist groups launch Molotov cocktails and bottles of milk against the homes of black kids. Unrest also spread to Tottenham and Acton. The facts of North Hill and North Kensington were unprecedented and the entire nation was shocked and began to protest against the violence.

After a year, the "Notting Hill Carnival" is organized, the first carnival of black culture, where thousands of people demonstrate against racism and discrimination, manifesting the need for a new policy, which starts with the acceptance of cultural diversity and for a multicultural society. The Notting Hill Carnival, which is still celebrated today, is one of the most important in Europe and certainly the most important in the United Kingdom.

\subsection{The Commonwealth Immigrants Act}

During the early Sixties, through family reunifications, there is a growing number of citizens coming from Pakistan. In 1960 the government set up a committee supervised by the «Richard Rab Bluter» to elaborate a new draft law on immigration. The draft law, ready in 1962, is named Commonwealth Immigration $A$ and considers the following requirements to enter the United Kingdom:

a. an empolyment contract;

b. a request from the employers, who expressed the wish to have that specific person as a worker;

All those belonging to the former colonies, but who had a British passport issued by the central government of the United Kingdom, and children born in Britain were excluded from the application of the law.

Many analysts have explained how this decree created a form of discrimination against British Asians, settled mainly in East Africa. These citizens were excluded from the citizenship of what was their only home state, thus becoming stateless. Passports issued by the former British colonies, indeed, did not have the same effect as those issued in the United Kingdom. Only the right to remain in the colonies was granted to them.

\subsection{The "Commonwealth Immigration Act"}

Very soon, with the achievement of independence, the issue of Asian minorities in the territories of Uganda and Kenya is also presented (Uganda Independence Act 1962, Kenya Independence Act 1963). The laws of these countries provided for foreigners and British Asians the obligation to apply for the acquisition of citizenship of the new countries within two years.

Between 1967 and 1968, Asians residing in Kenya and Uganda who had not accepted the aforementioned regulation or who had not applied in time, were discriminated and persecuted by the governments of the new independent states, forcing thousands of people to flee to the United Kingdom, guaranteed by the maintenance of British citizenship.

The most famous protester of the new entrances was Enoch Powell, who declared that it was impossible to accept new entrances, proposing to deprive the right of Asians coming from Africa to enter the country. There weren't few political parties and the media that supported this line of thought, fomented by the fear of an invasion in the United Kingdom by the Asians of the former colonies.

The prime minister of the time, Harold Wilson, proposes the introduction of The Commonwealth Immigration Act, which blocks the automatic entry of British colonial citizens; only those who were born or naturalized in the United Kingdom or had one of the family members with such status could enter. This decision entails a dramatic situation for the British asian citizens, blocked and detained if they tried to enter the United Kingdom. The same situation does not occur, however, for the British Europeans of the former colonies, which shows that at the basis of that measure there was an attitude of racial discrimination. 


\subsection{The entry into force of the Commonwealth}

The Immigration Act however went against the 1950 European Convention on Human Rights, signed by United Kingdom itself. The British Asians have tried to bring their problem to the attention of the European Parliament and the European Commission on Human Rights. In 1973 the commission will declare that England had violated in particular the art. 3 of the Convention and made unequal treatment, penalizing certain citizens for racial reasons. The Commission has also condemned the rejection of reunification of husbands whose wives are already resident in the United Kingdom.

\subsection{The Immigration Act}

The British parliament, under pressure from the conservative party, approved in 1971 the Immigration Act, which gives full power to the Home Office to regulate the entry of migratory flows, their stay and the expulsion from the British territory.

The main novelty of this law is the replacement of the British subjects and aliens with partials and non-partials, to distinguish who had the right of residence in the United Kingdom and who could not enter the territory (Bohning W. R,1972). Entry and stay requirements include birth, descent, adoption, residence on British soil for at least 5 years before the entry into force of the law and marriage with a British citizen. The members of the partials could have the right of abode (permanent residence).

If until the introduction of the law, entry and stay in the United Kingdom were based on the link of loyalty between the individual and the crown in any Commonwealth nation it was found, now the relationship between the subjects and the United Kingdom seen as a territory is integrated (Casari, 2010).

\subsection{The Race Relations Act of 1976}

In 1976 the first law on the illegitimacy of racial discrimination was issued, which declared illegal any discrimination on an ethnic basis, especially in the labour market and and at school, and it introduced the right to defend oneself and report discrimination in the labor courts.

The law provided for the establishment of the Commission for Racial Equality, which had essentially the task of eliminating discrimination and promoting equality of opportunities and good relations among people of different ethnicities. Furthermore, the Commission had the task of coordinating various local institutions in the field of immigration and in combating discrimination and racism.

\subsection{British Nationality Act (1981)}

The conservative government of Margaret Thatcher issues one of the most decisive laws about immigration and the acquisition of British citizenship, taking into consideration three parameters, or better "three types of British citizens":

1) British citizenship: full British citizenship for those citizens of the colonies who were patrial, and who had close ties with British citizens (grandparents, parents, spouse, children);

2) British Dependent Territories Citizenship: British citizenship to people from territories dependent on the crown, such as Gibraltar, the Falkland Islands and Hong Kong;

3) British Overseas Citizenship: that category to which the rights of citizenship had been excluded in the previous legislations (for example the British Asians of East Africa).

With the approval of this law the right of British citizenship is recognized to all those people to who it had been unjustly denied.

On one hand, the Thatcher government recognized and regulated the right of citizenship and permanent residence to certain groups that possessed the requisites listed above, but at the same time it took a strong stand against immigration, limiting residence on British soil to all those categories of people excluded from the same requirements. 
The return to the ius sanguinis is also decisive on the question of citizenship. Under the new legislation a child born in England from foreign parents must explicitly request British citizenship, proving to have resided in United Kingdom for at least the first 10 years of life.

Very soon there is a need for further legislative changes in the face of the changes that have occurred since 1997 in the former colonies. In that year the agreement with China expired and Hong Kong passed under the Chinese control; the new legislation for British citizens on the island takes the name of British National (Overseas).

With the Immigration and Asylum Act of 2002 the 1981 law is supplemented, guaranteeing British citizens overseas who had not yet been able to acquire the British citizenship, and who in the meantime had acquired no other citizenship, the right to enter and reside in the United Kingdom territory.

\subsection{Citizenship and Immigration Act of 2009}

This supplementary regulation grants the right to the children of members of the armed forces, born abroad during the service of their parents, to become British citizens (Montagna,. Sorrentino, 2004). I would like to analyze in more detail the current procedures for acquiring citizenship in the United Kingdom. As already mentioned, the fundamental law in this regard was the British Nationality Act.

Today, British citizenship is generally acquired as a birthright: if both parents, or at least one of them, is a British citizen when the child is born, or if at least one of the parents, even if they are not British citizens, has permanent residence in the United Kingdom territory.

Particularly interesting is the implementation of the law in particular cases, when none of the parents possesses neither citizenship nor residence on British territory. In this case, the child born in the British territory has the right to apply for citizenship if he / she spends at least 10 years here, with an absence not exceeding 90 days. In the event that one of the parents becomes a British citizen or moves to the United Kingdom and takes on permanent residence here, the child becomes a British citizen at the age of eighteen, upon his express request.

Finally, a person born in the United Kingdom can apply for British citizenship if one of the parents possesses the British passport of overseas settlers (eg Hong Kong) or has permanent residence for at least 5 years in the United Kingdom.

\subsection{Naturalization of foreign citizens applying for British citizenship}

British legislation allows foreign people to access British citizenship by naturalization. An example is the spouse or foreign partner of a British citizen, who can have the right to citizenship after a period of continuous cohabitation with the British citizen in the UK for at least 3 years. The applicant has the duty to demonstrate that he / she possesses the necessary requisites for naturalization, such as residence for at least three years, to have no pending suits with justice, to be of age and to have no mental health problems.

In cases where the request for citizenship is done outside of marriage or cohabitation with British citizens, the foreigner must prove that he possesses the requisites that are linked to his personal status, to be settled down in England in a regular manner for at least 5 years without interruption (with a maximum of 90 days per year of absence) and to have a suitable job and accommodation.

With the last decree of 2005 a further obligation was introduced, in a restrictive sense, to be precise the successful completion of two exams, one of language and one of British history and civilization.

The Home Office has activated a legislation after the terrorist acts that took place in London in 2005 , which opens up the possibility of rejecting requests for citizenship presented by foreigners, without warning and without giving any motivational explanations in this regard.

Furthermore, the new anti-terrorism decree provides for the revocation of British citizenship in cases where the foreign citizen, who had acquired citizenship through naturalization, is held responsible for having carried out acts against the interests of the homeland or for having declared falsehood. 


\section{Conclusions}

In the development of this work we have analyzed the most important reception and integration models adopted in Italy, the United Kingdom, France and Germany (Cespi, 2000). As we have seen, the migration policies of these countries are extremely different from each other, both for the individual regulations and for the theoretical paradigm to which they can be traced back (Pierre, 1978).

The French model is based on the concept of assimilation, the German one doesn't guarantee immigrants a system of specific rights, which respond to the needs of ethnic groups present in the territory, the English one, which is in particular multicultural, recognizes broad spaces for inclusion and integration into society.

The analysis of the Italian situation was preliminary: we observed how the immigrants who are in Italy are subject to the lack of a real model of reception and integration. This structural gap has been bridged by single legislative measures that seem, however, disconnected, if not even contradictory to each other.

Compared to the other countries examined, in the Italian case, the lack of a new idea in the treatment of the migratory phenomenon has meant that immigrants turn out to be excluded, making a real integration model impossible to occur.

\section{References}

Ascoli, U. (1979). Movimenti migratori in Italia, Bologna, II Mulino.

Bardet, JP. (1999). Cinquante ans d'immigration, in L'Histoire, Paris, Fevrier nº 229.

Barou, J. ( 1984). L'espace immigré au comment les rendre invisible" in Politique aujourd'hui, $n^{\circ} 6$,

Basteiner, E. (1990). Italia, Europa e nuove immigrazioni, (a cura di) DASSETTO, G. (1990), Torino, Fondazione Agnelli.

Bergnach, L., Sussi, E. (1993). Minoranze etniche ed immigrazione, Milano, Franco Angeli.

Bohning, W. R, (1972). The migration of workers in the United Kingdom and the European Community, London, Oxford.

Bolaffi, G. (1996). Una politica per gli immigrati, Bologna, II Mulino.

Bonifazi, C. (1998). L'immigrazione straniera in Italia, Bologna, II Mulino.

Bonnet, J.C. (1976). Les pouvoirs publics français et l'immigration dans l'entre-deux-guerres, Lyon, Presse Universitarie de Lyon.

Brusa, C. (1997). Immigrazione e multicultura nell'Italia di oggi, II territorio, i problemi, la didattica, vol I, Milano, Franco Angeli.

Bussetta, G. (1993). II governo propone in Francia il blocco totale dell'immigrazione, in II Sole 24 Ore, del 3 Giugno.

Caggiano, G. (2000). Migrazioni e diritto internazionale, in Agenzia romana per la Preparazione del Giubileo, Migrazioni. Roma, Scenari verso il XXI secolo, 12-14 Luglio.

Cala, A. (2010). La tolleranza spagnola nei confronti dei gitani, un modello per l' Europa?, Rai. Consultabile in: http://www.rai.it/dl/tg3/articoli/Contentltem-97e15fdd-c03c-4287-8ac6-1c92e60611da.html

Calcalaterra, M. (1998). La Francia allarga le maglie per regolarizzare gli immigrati”, in II Sole 24 Ore del 18 Agosto.

Calvanese, F. (1992). Spazi e tempi delle nuove migrazioni in Italia, Europa e paesi extraeuropei, in Mottura G. Arcipelago Immigrazione. Caratteristiche e modelli migratori in Italia. Roma, Ediesse.

Capano, T. (1999). La partecipazione politica" in Zincone G. (a cura di) Primo rapporto sull'integrazione degli immigrati in Italia. Bologna, II Mulino.

Carchedi, F. (2000). La condizione degli immigrati in Italia" in Agenzia romana per la Preparazione del Giubileo, Migrazioni. Roma, Scenari per il XXI secolo, 12- 14 Luglio.

Casari ,G. V. (2010). Il diritto dell'immigrazione (volume 2), Quaderni de "ll diritto dell'economia». Modena, Modena.

Castles, S., Miller, J, M. (1993; 1998) The Age of Migration, The migratory process. London, Makmillan Press LTD.

Censis. (2000). Processi globali e forme di governo delle migrazioni in Italia e in Europa. Una sintesi delle ricerche. In Agenzia romana per la preparazione del Giubileo, Migrazioni. Scenari verso il XXI secolo. Convegno internazionale, Roma 12-14 Luglio

Cespi. (2000). II governo dei processi migratori nel quadro europeo: obiettivi, strumenti e problemi" in CENSIS Processi globali e forme di governo delle migrazioni in Italia e in Europa. Una sintesi delle ricerche. 
Chemillier-Gendreau, M. (1998). L'injustifiable. Les politiques françaises de l'mmigration. Paris, Bayard Editions.

Colombo, A., Sciortino, G. (2004a). Gli immigrati in Italia. Bari, II Mulino, "Italian Immigration: The origins, Nature and Evolution of Italy's Migratory System", "Journal of Modern Italian Studies», volume 9, N 1 (2004b), pp. 49-70.

Corti, P. (2003). Storia delle migrazioni internazionali. Roma-Bari, Laterza.

Costa-Lascoux, J. (1999).L' integrationàlafrançais:unephilosophie, des lois", in Immigration et integration. L' etat des savoirs. Paris, De La Decouverte.

Costantini, D. (2009). Politiche migratorie e discriminazione: il caso francese. Questo articolo è stato realizzato grazie ai contributi della Commissione europea (FP6 - Euroethos), e del CNR (Progetto giovani ricercatori 2005), Dino Costantini. Consultabile in Archivio Marini: http://archiviomarini.sp.unipi.it/345/1/dis.pdf

Di Comite, L,. laquinta, P. (2002). L'emigrazione Italiana 1870-1970, Pubblicazioni degli archivio di stato.

Einaudi, L. (2007). Le politiche dell'immigrazione in Italia dall'unità a oggi. Bari, Laterza, pp. 4.

Einaudi, L.( 2007). Una gestione amministrativa oscillante tra tolleranza e repressione, Le politiche dell'immigrazione in Italia dall'unità a oggi, Bari, Laterza, pp. 98-99

Farini, L. C. Massima autorità politica del Mezzogiorno dopo l'Unita, Scriveva a Cavour dopo il suo arrivo a Napoli "Altro che Italia, questa è Africa". Può essere consultato in: http://www.identitaeuropea.it/?p=3203

Fassin, D. (1997). Les lois de l'inhospitalité. Les politiques de l'immigration à l'èpreuve des sans papiers, XIII. Paris, Editions La Decouverte

Gasperini, V, Casari. (2003). II diritto dell'immigrazione, Mucchi. In GEDDES, A. (2010), The politics of Migration and Immigration in Europe.

Gisti, (1997). Politiques migratoires dans l'Unionne européenne" in Troisiéme Meeting anti-racsiste du 23 Aout1 September.

Gerard, N. (2007). Immigration, antisémitisme et racisme en France (XIX-XX siècle). Discours publics, humiliations privées. Paris, Fayard.

Grillo, P. (1989). Scende in piazza I'Italia antirazzista, La Repubblica, 7 ottobre 1989.

Kammerer, P. (2003). Germania: un secolo di politica migratoria. In BASSO P., PEROCCO F, (a cura di), Gli immigrati in Europa, Milano, Franco Angeli.

La Stampa, 9 novembre 1996; Corriere della sera del 24/02/2009, I'intervista con Livia Turco del giornalista Lorenzo Salvia.

Livi Bacci, M. (2005) Storia minima della popolazione del mondo. Bologna, II Mulino.

Livi Bacci, M. (2010). In cammino, breve storia delle migrazioni. Bologna, II Mulino.

Madjiguene, C. (1996). Sans-papiers; i primi insegnamenti", in Politiqes del 2 Ottobre

Massey, S, D. (1993). Theories of International migration, population and development review, Vol 19.

Masslo Jerry, a South African refugee, was murdered in a shed in Villa Literno (CE), where he worked and slept with other immigrants by a group of thieves on the evening of 24 August 1989 because he refused to give his earnings. Possible consultation also in::http://www.lunaria.org/2017/08/25/28-anni-la-morte-jerry-essanmasslo/;http://napoli.repubblica.it/cronaca/2014/08/24/news/jerry_masslo_25_anni_dopo_le_iniziative_a_villa literno-94396197/

Melotti, U. (1991). Specificità e tendenze dell'immigrazione straniera in Italia" in Macioti MI., Per una società multiculturale. Napoli, Liguori.

Melotti, U. (1993). La sfida dell'immigrazione: aspetti generali e problemi specifici del caso italiano" in Bergnach L. e Sussi E., a cura di, Minoranze etniche ed immigrazione. Milano, Franco Angeli.

Melotti, U. (2004). Migrazioni internazionali, Milano, Mondadori, pp. 4-6.

Montagna, Di, N., Sorrentino, G. (2004). Vecchio continente, nuovi cittadini, normative, dati e analisi in tema di cittadinanza. Editing a cura di Laura Facchi. Rapporto Regno Unito, Fondo europeo per l'integrazione di cittadini di paesi terzi (Realizzato da ISMU)

Niessen, J., schibel, Y. (2007)). Manuale sullintegrazione per i responsabili delle politiche di integrazione e gli operatori del settore, Comunità Europea, pp. 14. Riproduzione autorizzata con citazione della fonte. Può essere scaricato dal sito della Commissione Europea all'indirizzo: http://ec.europa.eu/justice_home/ .

Noiriel, G. (2007). Immigration, antisémitisme et racisme en France XIX-XX siècle. Discours publics, humiliations privées, Paris, Fayard.

Perocco, F. (2012). Immigrati e disuguaglianza lavorativa nel sistema delle disuguaglianze italiane, Rapporto annuale sull'economia dell'immigrazione. Bologna, II Mulino.

Pierre, G. (1978). Le migrazioni internazionali. Roma, Editori Riuniti.

Pugliese, E., Macioti, MI. (1991). Gli immigrati in Italia. Bari, Laterza.

Pugliese, E. (2002). L'Italia tra migrazioni Internazionali e migrazioni interne. Bologna, II Mulino.

Riviera, A. (1998). Per una nuova cittadinanza, in Convegno organizzato a Roma Giugno

Ruzza, C. (, Sociologia delle relazioni etniche 1 Etnicità, Società Civile e Politiche Migratorie in Francia, pp. 171

Sayad, A. (2002). La doppia Assenza, Torino, Cortina Raffaello.

Sbai, S. (2002). L'inngano: vittime del multiculturalismo, Cantagalli,

Schor, R. (1996). Histoire de l' immigration en France, de la fin du XIX siècle à nos jouurs,. Paris, Armand Colin. 
Simone, A. (2002). Divenire Sans Papiers: Sociologia dei dissensi metropolitani. Milano, Associazione Culturale Etertopia.

Taieb, E. (1998). Immigrés: l'effet génération. Paris, Les Editions de L'Atelier.

Tomei, G. (2001). Città, cittadinanza e welfare municipale. Viareggio, Mauro Baroni Editore.

Treves, A. (1976). Le migrazioni interne nell'Italia Fascista, Einaudi.

Tribalat, M. (1997). Cent ans d'immigration, étrangers d'hier français aujourd'hui. De l'immigration à l'assimilation. La Decouverte, Paris.

Volpi, A. (2007). Mappa mondo Post globale. Milano, Terre di Mezzo.

Weil, P. (1995). La France et ses étrangers. L'aventure d'une politique de 'immigration de 1938 à nos jours, Paris, Gallimard. In: GOBETTI, E. (2007). 1943-1945 La lunga liberazione, Milano, Franco Angeli,.

Zincone, G. (2007). Primo rapporto sull'integrazione degli immigrati in Italia, Bologna.

\section{Consulted}

Caritas-Italiana - Fondazione Migrantes, Dossier Statistico Immigrazione Caritas-Migrantes 2011 http://www.caritasitaliana.it/home_page/pubblicazioni/00002486_Dossier_Statistico_Imm igrazione_Caritas_Migrantes_2011.html

Nord E Sud Del Mondo, Rapporti Assimetrici Nell'era Della Globalizzazione http://www.caritas.vicenza.it/contentimages/nord_sud_superiori.pdf

La Casa Degli Albanesi D'italia, http://www.arbitalia.it/storia/migrazioni.htm

Cose Di Scienza, http://www.cosediscienza.it/varie/03_migrazioni.htm

Office of the Historian, http://history.state.gov/milestones/1921-1936//mmigrationAct

International Migration Outlook-Rapporto Osce-Sopemi 2010, http://www.cnel.it/271?shadow_documento_altri organismi $=3370$

Organization for Security and Co-Operation in Europe, http://www.osce.org/

International Migration Outlook"- Rapporto OCSE-SOPEMI 2010

Normativa 943/1986 http://www.normattiva.it/uri-res/N2Ls?urn:nir:stato:legge:1986- 12-30;943

Comissione Per Le Politiche Di Integrazione, http://www.pavonerisorse.it/intercultura/2001/integrazione

Organizzazione Internazionale Per Le Migrazioni, Centro studi e ricerche Idos, Roma, 2012

Convenzione Dei Diritti Dell'uomo, Corte Europea Dei Diritti DELL'UOMO http://www.echr.coe.int/echr/

British Nationality Act http://www.uniset.ca/naty/BNA1948.htm, http://www.nationalarchives.gov.uk http://www.legislation.gov.uk

www.affarisociali.it

www.bok.net/pajol/sanspapiers - www.cestim.com

www.cronologia.it

www.romaciviva.net

www.unimondo.org 